\title{
PELUANG DAN STRATEGI PENJUALAN MELALUI INTERNET MARKETING
}

\section{Munawaroh*}

\begin{abstract}
The purpose of this journal is to mention of how the opportunity of internet marketing and the strategy of selling via internet marketing, The community of Indonesian now become the potential buyer because more than 30 million users of internet in Indonesia now. So that, this is the challenge for us to make the business based on e-commerce and application the strategy of selling via internet marketing.
\end{abstract}

Keywords: opportunity, strategy, e-commerce, internet marketing,

\section{PENDAHULUAN}

Internet marketing tampaknya sudah tidak lagi dianaktirikan di Indonesia, Lihat saja, dengan semakin banyaknya perusahaan-perusahaan nasional di Indonesia yang mulai mengkomposisikan anggaran pemasaran mereka ke sektor ini. Data menunjukan, pergerakan yang signifikan mengenai jumlah pengguna internet di Indonesia, ditambah lagi dengan ketatnya persaingan para provider telekomunikasi menyelenggarakan layanan internet marketing dengan harga yang semakin terjangkau dan layanan yang membaik, merupakan awal dari kebangkitan dunia internet marketing di Indonesia.

Hal ini tidak bisa di pungkiri, bahkan perusahaan search engine terbesar, Google.com, telah melirik dan menangkap gelagat akan meledaknya dunia internet marketing di Indonesia dengan meluncurkan program periklanan seperti google

Munawaroh. Dosen Fakultas Ekonomi Universitas Negeri Jakarta. adsense untuk versi Indonesia. Semoga gejolak pasar ini akan menjadi hal yang bermanfaat bagi para penjual melalui internet (netmarketer) yang dulunya begitu pesimis dengan online marketing di Indonesia.

Menurut Lennart Svanberg, Presiden World Association of Internet Marketers, semakin banyak perusahaan akan 'go internet, dan tidak akan ada perusahaan yang tidak 'go internet bila mereka tidak ingin punah (walau ini bukan jaminan kalau mereka tidak mengetahui kekuatan dari strategi pemasaran di dunia online). Ya kita harus tahu tentang "pemasaran internet".

Banyak perusahaan termasuk di Indonesia sebenarnya mampu dan memiliki anggaran untuk melakukan itu, namun sayang sekali mereka tidak mempunyai kompetensi untuk melakukan itu dan mereka berupaya menjangkau dunia online dengan metode pemasaran tradisional. Pertimbangan konsep pemasaran tradisional adalah segmentasi pasar, 
yaitu suatu metode untuk mengenali sekelompok konsumen, di dalam suatu pasar yang lebih luas, yang memiliki karakteristik dan kebutuhan yang mirip.

Sekarang dengan meledaknya pertumbuhan internet, dunia bisa menjadi pasar kita yaitu, "sekelompok konsumen" yang dapat dijumpai secara online. Untuk dapat mengidentifikasi segmen pasar yang baru ini mengharuskan kita mengenali dan mengimplementasi berbagai macam strategi dan teknik baru sebagai tambahan dari strategi pemasaran konvensional. Bagaimana dengan perusahaan di Indonesia?

Mungkin kita selalu berpikir kalau perusahaan di Indonesia selalu terbelakang dalam masalah internet. Pikiran yang tidak sepenuhnya benar. Dengan adanya komunitas pengguna internet sebesar 40 juta orang online, yang sebagian besar adalah berusia 15 - 35 tahun, maka penetrasi pasar yang didukung oleh jaringan $3 G$ connection, wifone, cable internet dan lain sebagainya, internet di Indonesia sangat berpotensi.

Saat ini banyak perusahaan yang berusaha menembus komunitas internet di Indonesia, contohnya Djarum Super dengan extension brand mereka SuperSoccerGame. SuperSoccerGame adalah suatu turnamen futsal ala Djarum yang diadakan tiap tahun dan mereka bermain dengan cara yang unik yaitu di dalam kandang dan berhadiah total Rp.200 juta. Ketika Djarum berusaha membuat SSG ini menjadi populer, salah satu cara yang mereka tempuh adalah dengan menggunakan online approach.
Djarum mengerti kalau di dalam internet banyak komunitas dari pangsa anak muda yang ditargetkan untuk datang menonton acara mereka. Djarum membuat kampanye viral marketing yang bertugas dalam mengedukasi komunitas anak muda dengan menggunakan video-video yang sangat unik dan lucu sehingga menjadi e-mail berantai yang merambah ke seluruh komunitas.

Sedangkan untuk pusatnya mereka meluncurkan website baru yang khusus dibuat untuk kaum para pengemar SSG, futsal, street ball, freestyler dan beach soccer untuk mewadahi para fans untuk saling bertemu dan menginsipirasikan para pemain agar bermain lebih baik. Mereka pun mempunyai komunitas mailing list untuk mewadahi para fans dan pemain futsal, freestyler dan yang lain untuk bertukar pengalaman dan juga untuk bertemu secara online.

Selain Djarum, banyak pula perusahaan yang telah memasuki era internet untk menggapai segmented market yang sangat niche. Hal yang menarik dari internet adalah interaksi dengan customer yang bisa terukur dan juga bisa membuat loyalitas dari customer bertambah kalau ditata kelola dengan baik.

Penetrasi internet didukung oleh beberapa pihak, yaitu:

1. Jaringan, seperti $3 G$ connection, GSM/CDMA dan cable Internet, contohnya Speedy.

2. Medium, seperti Komputer, Notebook, Netbook, HP, Balckberry dan Ipad.

3. Content Providers seperti supply contents, contohnya Boleh.com. 
4. Consumers merupakan konsumen pemakai internet.

Pihak tersebut berperan penting dalam memasarkan internet secara keseluruhan. Karakter konsumen Indonesia di bidang internet sangat berbeda dengan negara lain terutama negara berkembang. Sebagian besar komunitas internet Indonesia hanya mengakses konten entertainment seperti chatting, facebook dan berita.

Salah satu contoh e-commerce yang berhasil di Indonesia adalah Airasia.com. Airasia secara tidak langsung 'memaksa' konsumen menggunakan internet untuk memesan tiket dengan harga murah. Mungkin akan lebih meledak lagi jika para provider telekomunikasi di Indonesia, menyertakan edukasi tentang dunia internet dengan segala "kelebihannya", seperti yang dilakukan Indosat M2 di Bali yang mulai menfasilitasi perkembangan dunia internet marketing untuk UKM di Bali.

\section{Pemakai Internet di Indonesia}

Pengguna internet di

Indonesia pada tahun 2010 yang lalu mencapai 30 juta pemakai. Angka yang menakjubkan jika mengingat pada tahun 2000 jumlah pemakai internet hanya 2 juta pemakai. Jadi, dalam jangka waktu 10 tahun pertumbuhan pengguna internet di Indonesia meningkat lebih dari $1500 \%$ !.

Total jumlah penduduk Indonesia adalah sekitar 240 juta, 30 juta pemakai hanya sekitar $13 \%$ kurang sedikit dari total jumlah penduduk. Jumlah penduduk
Indonesia yang "melek komputer", angkanya tidak akan melebihi dari $25 \%$ dari jumlah penduduk kita, karena yang mampu mengecap pendidikan sampai kuliah tidak terlalu banyak, belum lagi dihubungkan dengan masalah kemampuan ekonomi. Tapi mengapa terjadi pertumbuhan yang sedemikian signifikan 10 tahun terakhir, jawabannya ada di kalangan muda usia, mengapa hal tersebut terjadi?

Apakah internet sudah menjadi barang murah? Sepertinya tidak begitu jawabannya karena untuk mendapatkan sebuah koneksi internet masih agak mahal yang harus dikeluarkan oleh masyarakat Indonesia, entah installment fee atau harga para internet provider Indonesia memberikan harga tinggi dengan sistem bandwidth yang dipakai. Hal ini tidak masuk akal dan menjadi mahal pada akhirnya, kemudian dari mana asalnya pertumbuhan ini?

Ada beberapa faktor yang menjadi penentu pertumbuhan pemakai internet, yaitu:

Pertama sudah banyak sekolahsekolah yang menyediakan internet gratis atau paling tidak memiliki laboratorium komputer dengan koneksi internet, ditambah dengan sudah banyak kampus yang menyediakan wifi connection gratis, serta didorong harga notebook/laptop yang makin murah.

Kedua, dari perusahaanperusahaan di Indonesia, bahkan sekarang di pemerintahan setingkat pemerintahan daerah sudah mensyaratkan fasilitas internet untuk karyawannya. 
Bisa dilihat dari tingkat pemakaian koneksi internet yang tinggi hanya terjadi di saat hari kerja atau hari sekolah yaitu hari Senin sampai Jumat, sedangkan di hari Sabtu dan Minggu koneksi internet mengalami penurunan yang sangat drastis. Hal ini sudah dideteksi oleh pihak Telkomnet Instant, sehingga Telkomnet Instant pernah mengeluarkan paket weekend dengan harga "agak" miring.

Siapakah para pemain terbesar di internet Indonesia? Mungkin sudah bisa ditebak dengan mudah, yaitu para karyawan kantor, anak-anak yang sedang di sekolah baik SMP, SMA dan Perguruan Tinggi. Sebuah peluang pasar yang niche dan segmented. Peluang ini bisa menjadi sebuah ancaman, atau sebaliknya. Dalam hal ini malah menjadi peluang positif, mengapa demikian?

Dapat dibayangkan jumlah 30 juta pemakai internet di Indonesia yang merupakan:

1. Karyawan/usia kerja produktif

a. Memiliki buying power, keputusan pembelian sudah pasti ada ditangan mereka.

b. Kalangan yang memiliki intelektual, ini memastikan tidak semua produk dapat berpromosi via internet atau cara-cara yang pasti berbeda dengan di televisi, tanpa pelawak, slapstick murahan atau hard sell yang membuat orang-orang kecewa.

2. Para pelajar

a. Anak muda usia 10 - 16 tahun. b. Memiliki pengaruh besar ke keluarga dan teman-teman dalam urusan mempengaruhi keputusan pembelian.

Kedua kalangan ini memiliki potensi yang mengerakkan dalam proses pembelian, yaitu karena di hormati tingkat pengetahuannya dan menjadi sumber informasi atau role mode/ dalam sebuah kelompok.

Strategi lanjutannya adalah bagaimana mengkomunikasikan bahwa produk/merek sendiri yang dipunyai memiliki banyak kelebihan dibandingkan kompetitor, disin keunggulan dunia internet, karena memiliki waktu yang lebih panjang untuk mengedukasi pasar dan memiliki tempat/space yang tidak terbatas untuk menginformasikan kehebatan produk/merek sendiri.

\section{Strategi Penjualan melalui Internet Marketing}

Sekarang ini internet sangat membantu para penjual untuk meningkatkan pendapatan perusahaan ataupun pemilik usaha. Teknologi ini bisa membantu jika masyarakat diedukasi bahwa pembelian melalui internet tidak berbahaya atau kemungkinan terjadinya penipuan tidak terjadi (minimal pada toko kita), karena sekarang sangat marak terjadi penipuan bahkan kejahatan kartu kredit melalui internet.

Lalu kalau internet digunakan sebagai sarana penjualan ritel seperti kaos, celana dan sebagainya (produk fashion), maka penjual sebaiknya memberikan kesempatan kepada calon pembeli untuk mencobanya nanti pada saat barang yang ingin dibeli di antar 
ke lokasi yang disepakati. Karena kemungkinan perbedaan ukuran badan dan baju/celana sehingga kadang keputusan membeli ditentukan pada saat mencoba. Berbeda dengan $\mathrm{CD} /$ elektronik yang bisa memberikan jaminan/garansi selama waktu tertentu dan kalau buku yang sudah pasti tidak bisa dibaca semuanya dulu sebelum dibeli.

Untuk barang interior set bisa ditampilkan gambar dalam format high resolution. Customer dapat melihat dengan jelas barang yang ingin dibeli, dan bisa dibuatkan beberapa gambar yang menampilkan produk interior dalam beberapa ruangan yang berbeda.

Strategi penjualan di bidang online shopping cukup berpotensi karena tidak terlalu membutuhkan banyak biaya serta dapat membina hubungan yang baik dengan pelanggan.

Untuk langkah awal mungkin hanya memerlukan biaya promosi untuk iklan di website yang ratingnya tinggi seperti detik.com dan biaya tambahan untuk biaya pengiriman, yang jika memungkinkan dapat digratiskan untuk sejumlah pembelian tertentu.

Ada sedikit opini tentang berbisnis dengan menggunakan medium internet atau sering dikenal dengan e-commerce di Indonesia. Sebagai salah satu sarana e-commerce yang bisa menjadi tempat untuk meningkatkan transaksi adalah melalui berbagai forum, seperti www.kaskus.com, Forum-forum ini menyediakan bagian khusus untuk jual beli. Sarana ini bisa dipakai untuk meng-upload gambar barang-barang yang akan dijual dalam forum tersebut, Tentu saja sekalian menyisipkan website yang kita miliki. Komunitas online seperti ini sudah mulai terbiasa dengan transaksi online yang berasaskan saling percaya. Kredibilitas pembeli dan penjual sangat dipandang tinggi dalam forumforum seperti ini. Bila ada penjual atau pembeli yang curang, maka orang yang dirugikan dapat menulis pengalaman dengan orang tersebut di forum itu. Orang tersebut akan diblacklist oleh member lainnya. Sebaliknya bila transaksi yang dilakukan berjalan lancar, maka mereka akan merekomendasikan penjual tersebut kepada member yang lain.

Tahun 2010 yang lalu, pengguna internet di Indonesia terbesar di Asia Tenggara. Kedepan pertumbuhan pengguna internet di Indonesia juga akan terus bertambah dengan pertumbuhan yang mengagumkan.

Sebelum mulai berbisnis dengan menggunakan medium internet, perlu diketahui dahulu karakter medium ini dan perbedaannya dengan medium biasa. Beberapa hal dasar yang perlu dipertimbangkan ialah:

1. Tampilan: Pada toko tradisional, pelanggan bisa menyentuh barang yang hendak dibelinya, bisa mencobanya, merasakan teksturnya dan bahkan mencium harumnya. Sedangkan pada melalui internet hanya dapat menggunakan gambar, grafik, dan teks untuk mendeskripsikan produknya. Hal ini berimplikasi pada karakter produk yang akan 
dipasarkan. Produk-produk yang bersifat standar seperti elektronik atau buku, sangat potensial dipasarkan dengan medium ini, sedangkan produk yang perlu bantuan peran oleh panca indera seperti harus dirasa, harus dipegang, harus dicium terlebih dahulu akan lebih sulit dipasarkan di internet, apalagi jika produknya benar-benar tidak ada di toko lain. Berbeda jika produk tersebut memiliki merek yang terkenal dan kualitas yang sudah dikenal seperti parfum CK. Bila transaksi tersebut bersifat B2B (Business to Business) maka pengiriman contoh menjadi alternatif yang baik untuk mengatasi hambatan ini.

2. Pengeluaran: Walaupun dalam medium internet tidak dibutuhkan biaya untuk menyewa tempat atau kantor, namun perlu diingat pengeluaran lain untuk mendesain dan membangun web e-commerce yang kemungkinan akan menghabiskan anggaran yang cukup besar, bila ingin pengembangan e-commerce yang serius. Solusi lainnya ialah bergabung dengan e-marketplace yang ada atau e-mall yang didalamnya terdapat beberapa toko terpisah. Pengeluaran lainnya ialah biaya untuk maintenance online shop tersebut tentunya perlu juga dihitung.

3. Lokasi: Medium internet mempunyai lokasi yang tidak dibatasi oleh batas geografis. Karenanya ada beberapa implikasi yang perlu dipertimbangkan, yaitu produk atau jasa yang ditawarkan harus unik, tidak hanya di lingkungan sekitar tempat penjual namun juga secara nasional dan internasional. Karena pesaing Anda juga sebenarnya adalah online shop seluruh dunia. Walaupun masalah biaya logistik biasanya menjadi hambatan alami dalam transaksi, tetapi tidak tertutup kemungkinan produk akan dipesan oleh mereka yang tinggal di Amerika Serikat atau negara di benua Eropa. Pernah terjadi, seseorang membeli barang dari Australia yang biaya kirimnya lebih besar dari harga produknya itu sendiri.

4. Komunikasi: Faktor komunikasi yang baik menjadi penting karena lebih susah berkomunikasi melalui medium internet ini dari pada komunikasi berhadapan muka secara langsung (face to face). Karena itu usaha ekstra diperlukan untuk memastikan agar tidak terjadi salah paham dalam pembelian, respon yang cepat terhadap e-mail dan pertanyaan pelanggan.

5. Teknologi: Dasar dari medium internet ialah teknologi, perlu disadari dari awal kalau dalam perjalanannya akan banyak terdapat berbagai update teknologi yang harus terus diikuti berikut dengan standar-standar baru yang mungkin akan muncul kedepannya.

6. Budaya: Budaya untuk membeli melalui internet tentunya berbeda dengan budaya membeli biasa, karena disamping membutuhkan kepercayaan yang tinggi terhadap 
toko online tersebut (juga terhadap medium internet), pelanggan juga harus memiliki keterampilan menggunakan internet. Disisi lain kebiasaan mencoba dan menawar dapat juga menjadi hambatan.

Beberapa faktor yang disebutkan memang sudah dapat mewakili untuk ikut "meramaikan" toko online, namun yang terpenting yaitu kontribusi yang jelas dari pemerintah. Misalnya dengan mendirikan suatu badan penjamin agar tercipta suatu kepercayaan dari sisi konsumen, juga sebagai lembaga yang pada akhirnya melindungi hak dan kepentingan konsumen. mengingat tingkat kepercayaan masyarakat kita masih lemah.

Saat ini e-commerce di Indonesia masih belum bisa menjamur seperti di Amerika atau negara maju lainnya, salah satu sebab adalah tidak adanya dukungan dari pihak ketiga yang berwenang untuk bisa memberikan keamanan transaksi bagi pihak penjual dan pembeli. Pihak ketiga adalah yang berwenang baik pemerintah, lembaga perlindungan konsumen atau badan otorisasi keuangan lainnya, contohnya seperti Paypal di Amerika Serikat.

Dengan tidak adanya keamanan ini maka menciptakan suasana yang kurang kondusif sehingga website online di Indonesia bisa dikategorikan "banci", yaitu dari sisi desain dan fungsionalitas bagus, tapi kadang harus telepon dulu, konfirmasi ulang, transfer, telepon lagi, dan masih banyak proses yang kurang efisien. Padahal website di
Indonesia sudah tidak kalah dengan website e-commerce di luar negeri, hanya lemah pada sistem pembayarannya saja.

Sebagai salah satu "online" retailer di Indonesia yang menjual berbagai macam barang elektronik kita juga merasakan kesulitan ini. Seharusnya jika ada pihak ketiga yang mau "repot" memberikan jasa layanannya sebagai payment portal justru bisa menjadi peluang yang besar di Indonesia.

Ada beberapa faktor yang
menjadi pertimbangan dalam menerapkan strategi melalui internet marketing, yaitu:

1. Jika yang dijual aksesori/pakaian/tas, pastikan foto yang terpajang cukup jelas, lebih baik jika ada foto dalam beberapa sudut pandang, sehingga bisa menarik minat seseorang. Foto adalah kunci utama.

2. Tidak selalu setiap pembelian yang sifatnya visual driven orang harus melihat langsung, selama foto yang terpajang jelas, cukup menjawab rasa ingin tahu.

3. Sesuatu yang dibeli berdasarkan ukuran, jangan lupa cantumkan ukuran yang tersedia plus sediakan juga layanan untuk mencoba.

4. Keunggulan layanan antar ini adalah pelanggan merasa dilayani seperti raja. Tidak perlu keluar rumah, barang bisa pilih, dan biaya bisa lebih murah, karena tidak mengenakan biaya sewa ruangan.

5. Pembayaran sebaiknya fleksible, bisa menggunakan credit card 
atau dibayarkan langsung saat barang diterima (diantar kurir).

6. Website disini fungsinya lebih untuk memajang produk dan menunjukkan harga.

Beberapa tips untuk customer yang menuntut kehati-hatian terhadap penipuan:

1. Berikan keyakinan bahwa kita tidak bermaksud menipu.

2. Berikan alamat yang jelas dan nomor telepon yang mudah dihubungi.

3. Apabila perlu, masukkan referensi di website berupa customer testimonial, dimana customer memberikan rekomendasi terhadap pemilik/penjual dan produknya, tapi jangan lupa meminta ijin terlebih dahulu kepada customer yang bersangkutan.

4. Berikan jaminan uang kembali, dimana apabila dalam jangka waktu tertentu (1-2 minggu) customer tidak puas dengan produk yang dibeli, maka customer dapat mengembalikannya, dengan syarat tidak ada cacat pada produknya. Disarankan jangan dikembalikan seluruhnya, diatur dalam syarat dan ketentuan yaitu dipotong biaya pengemasan/bungkus, pengiriman, dan sejumlah biaya modal yang terhambat.

5. Faktor lain yang harus diperhatikan adalah pembelian berulang (repeat buying). Usahakan menjalin hubungan erat dengan customer, dan berharap mereka terus melakukan repeat buying. Repeat buying, tidak akan sealot pembelian pertama, customer tidak perlu lagi diyakinkan mengenai barang dan validitas penjual, dan juga repeat buying merupakan pertanda bahwa customer yang bersangkutan melakukan promosi mengenai produk, minimal dengan cara getok tular (words of mouth).

6. Terakhir, dan tidak kalah pentingnya adalah jangan melakukan MLM, money game, arisan, skema piramida atau halhal lain semacam itu, karena hal itu akan memberikan citra yang buruk bagi website, produk dan pemilik/penjual di dunia maya.

Berbisnis diinternet akan lebih baik bila kita menyediakan apa yang dibutuhkan pasar, bukan apa yang dipunyai. Jangan membatasi hanya menjual untuk pasar di Indonesia saja, tapi untuk seluruh pengguna internet di seluruh dunia. Karena disini letak kelebihan internet sebagai "/everage" untuk menghasilkan banyak uang. Memang tidak akan mudah, namun juga tidak terlalu sulit karena ada tools dan trik yang harus dipelajari dan masih bisa diterapkan untuk bisa sukses di bisnis ini.

\section{SARAN}

Mempertimbangkan berbagai hal di atas, maka disarankan 4 langkah inti untuk menjalankan suatu penjualan on-line melalui internet marketing, yaitu:

1. Strategy (Strategi): Merumuskan dengan jelas segmen pasar internet yang akan dilayani, tentukan target dan yang terpenting positioning produk yang 
akan di tawarkan. Produk yang akan ditawarkan dan harga menjadi penting dalam dunia online, mengingat kompetitornya ialah pasar global, dan pelanggan dengan sangat mudah membandingkan harga dari toko online lainnya. Diferensiasi produknya jelas dan tentunya memiliki value dimata target pasar.

2. Operation (Operasional): Pastikan tidak hanya unsur online shop-nya saja yang siap, tapi harus memastikan sisi kesiapan logistik dan pengiriman barangnya. Perlu diingat bahwa pengiriman yang tepat waktu akan menimbulkan kepercayaan. Tidak hanya pengiriman, namun juga support (dukungan) dan service (pelayanan) yang baik dan prima.

3. Marketing (Pemasaran): Sebaiknya pola pemasaran dijalankan secara offline dan online. Banyak tools yang tersedia baik offline ataupun online tools. Online tools mulai dari SEO (Search Engine Optimizer) yang handal, menggunakan komunitas dan social network, viral, dan sebagainya.

4. Maintenance (Pemeliharaan): Kunci sukses suatu online shop pada akhirnya ditentukan oleh maintenance yang baik. Maintenance meliputi konten yang terbarukan, secara online system tidak ada kesalahan, selalu diperbarui, respon pelanggan yang cepat, pengiriman yang tepat waktu, kualitas barang yang sesuai dengan yang dijanjikan dan semua itu harus dijalankan dengan konsistensi yang tekun.

Selamat mencoba melakukan penjualan melalui internet marketing dan semoga berhasil menjadi penjual yang sukses. Go...Online Shopping...!

\section{DAFTAR PUSTAKA}

Elcom. 2010. Mudah Membuat Toko Online Oscommerce. Jakarta: Elex Media Komputindo.

Lovelock, C., Wirtz, W. 2011. Services Marketing - People, Technology, Strategy, $7^{\text {th }}$ ed. Golbal Edition. Pearson Education Inc., Publishing as Prentice Hall, New Jersey- USA.

Kotler, P. \& Keller, K.L. 2009. Manajemen Pemasaran Jilid 1 \& 2. Jakarta: Indeks.

Pusat Info Team. 12 Januari 2011. Internet Marketing - Internet Perusahaan Pemasaran - Internet Marketing Penelitian. http://www.pusatinformasionline.c om/internet-marketing-internetperusahaan-pemasaran-internetmarketing-penelitian/index.html. Diakses pada tanggal 1 Juli 2011. Pusat Info Team. 21 Februari 2011. Strategis Internet Marketing Newport Internet Marketing Internet Marketing Bussines. http://www.pusatinformasionline.c om/strategis-internet-marketingnewport-internet-marketinginternet-marketingbussines/index.html. Diakses pada tanggal 1 Juli 2011.

Pusat Info Team. 4 Maret 2011. Internet Marketing Untuk Tumbuh Pelanggan Situs Online. http://www.pusatinformasionline.c 
om/internet-marketing-untuk-

tumbuh-pelanggan-situs-

online/index.html. Diakses pada tanggal 1 Juli 2011.

Pusat Info Team. 18 April 2011.

Internet Marketing Teknik.

http://www.pusatinformasionline.c

om/internet-marketing-

teknik/index.html. Diakses pada tanggal 1 Juli 2011.

Pusat Info Team. 18 April 2011. Keuntungan Pemasaran Internet Atau Cara Mudah Untuk Memilih Guru.

http://www.pusatinformasionline.c om/keuntungan-pemasaraninternet-atau-cara-mudah-untukmemilih-guru/index.html. Diakses pada tanggal 1 Juli 2011.
Saiman, L. 2009. Kewirausahaan, Teori, Praktik dan Kasus-kasus. Jakarta. Penerbit Salemba Empat.

Salim, Joko. 2010. Step by Step Toko Online. Jakarta: Elex Media Komputindo.

Sukarto \& Susanto, Hianoto. 2009. Sukses Berbisnis di Internet dalam 29 Hari: Panduan Praktis. Jakarta: Elex Media Komputindo.

Zimmerer, Thomas W., Scarborough, Norman M., dan Wilson Doug. 2009. Kewirausahaan dan Manajemen Usaha Kecil, edisi 5. Jakarta. Penerbit Salemba Embat. 